\title{
The Autecological Characteristics of Endangered Medicinal Plant Thymus capitatus, in the Western Mediterranean Region of Egypt
}

\author{
Amal Mohamed Abdel-Rahman ${ }^{(1) \#}$, Masarrat Mohamed Abdelaziz Migahid ${ }^{(2)}$ \\ (I) Botany and Microbiology Department, Faculty of Science, University of Alexandria, \\ Alexandria, Egypt; ${ }^{(2)}$ Biology and Geology Sciences Department, Faculty of Education, \\ University of Alexandria, Alexandria, Egypt.
}

\begin{abstract}
7 HYMUS capitatus L. is one of the most important plants used in traditional medicine mainly in combating the growth of some pathogenic bacteria and reduce pathogen colonization in colon. This species is endangered in the study area due to the destruction in habitats. This study aims to evaluate the distribution of studied species in western Mediterranean region of Egypt, to determine the factors that affect its abundance in relation to soil characters and determine the associated species. Thymus capitatus was abundant in rocky ridge sites more than those in sand dunes and that their distribution in all sites was uniform. However, the covering diameter was larger in sand dunes sites that are characterized with higher $\mathrm{K}^{+}$content. The frequency of associated species in Thymus communities did not show any negative allelopathic effect between them. The present results indicate that Thymus capitatusis dominant in rocky ridges while it had been disappeared in inner rocky ridges as a result of human activities. They also indicate an important role of $\mathrm{K}^{+}$for Thymus capitatus growth. These results could provide us with well understanding of the suitable habitat of Thymus capitatus to contribute in the conservation ways.
\end{abstract}

Keywords: Threatened species, Vegetation, Remedial wild species, Hopkin index.

\section{Introduction}

The western Mediterranean desert of Egypt characterized by prominent variations such as physiographic and edaphic led to a differentiation into different types of habitats. Information on the distribution of plant communities in different locations has been documented by Abdel-Razik et al. (1984). Topographic factors have produced a very diverse microclimate and edaphic conditions which effect on the species adaptation to salinity or drought stress levels. The correlation between plants with abiotic and biotic factors in different ecosystems is usually a part of ecological researches. The distribution, pattern and richness of plant species have been related to physical and chemical soil characters and anthropogenic disturbances (Enright et al., 2005). There are many medicinal plants in Egypt but there is deficiency in the knowledge about plants condition for planting and their utilization. The aromatic pharmaceutical plants have been used traditionally as an important source of natural drugs, vegetables and spices for many centuries (Salehi et al., 2005).
The medicinal species in Egypt is subjecting to many threatens due to different factors of human actions include commercial development and tourism especially the continuous building of summer resorts, collection for medicinal uses and scientific research, in addition to aridity and irregularity of rain fall, variation of climate and drought series (Shaltout \& Ahmed, 2012 and Abdelraouf et al., 2015). Threats to the world's plant diversity continue to increase as a result of human activities (Raven, 2006).

The Labiatae (Lamiaceae) is one of the most distinctive flowering families with more than 200 genera and almost 4000 species worldwide. The most species in this family have an almost cosmopolitan distribution. Genus Thymus L., includes numerous species with quite morphological, anatomical and medicinal properties. It contains of about 215 species of herbaceous perennials and sub-shrubs that naturally grow in the Mediterranean region (Bounatirou et al., 2007) and it is represented in the Egyptian flora by 2 species (Tackholm, 1974). One of them is endemic to western Mediterranean

\#Corresponding author email: Elmasry_amal@yahoo.com

DOI: 10.21608/ejbo.2019.5957.1240

Edited by: Prof. Dr. Dimiter Ivanov, Scientific Secretary, Bulgarian Academy of Sciences, Bulgaria.

C2019 National Information and Documentation Center (NIDOC) 
region. Thymus capitatus L. is an aromatic medicinal species and perennial subshrub (Chaemephyte) and it is distributed in the western Mediterranean region. Leaves and flowers of Thymus species are commonly used as herbal tea, flavor agent and medication. Furthermore, Thymus extracts and its oils are commonly used in pharmaceutical, perfume, cosmetic industries and are also used for protection of food products (Ismaili et al., 2004). Imelouane et al. (2009) investigated that Thymus species have stout anti-parasitic, antifungal, antibacterial, antiviral, spasmolytic and antioxidant activities. Recently, Dzamic et al. (2015) reported that $T$. capitatus could protect colon epithelium against pathogenic colonies.

There are numerous reports (Hedhilia et al. 2005; Miguel et al., 2005 and Miceli et al., 2006) on the chemical composition, antioxidant and antimicrobial activities of essential oil (EO) of Thymus capitatus collected from different localities of its natural distribution. In all studies, the species are found to be rich in thymol and its isomer carvacrol which constitutes the main phenolic compounds of essential oil, followed by their biosynthetic precursors, p-cymene and c-terpinene as the other main compounds. Literature data showed strong bioactive potential of $T$. capitatus EO and it is mainly attributed to the high percentage of phenolic compounds such as thymol and carvacrol. Antibacterial, antifungal, anti-inflammatory, cytotoxic, herbicidal and insecticidal properties of thymol and carvacrol have been determined by several authors (Satooka \& Kubo, 2012; Llana-Ruiz-Cabello et al., 2014 and Gholijani et al., 2015).

The main objective of this work is to determine the environmental characteristic of the endemic medicinal plant species $T$. capitatus to detect its most suitable habitat for the aim of protecting it from extinction.

\section{Materials and Methods}

\section{Description of the studied area}

The selected area is located in the coastal region of the western desert of Egypt (Fig. 1). This region is situated between $30^{\circ} 80^{\prime}$ to $31^{\circ}$ North latitude and $29^{\circ} 30^{\prime}$ East longitudes. The means of precipitation is less than $200 \mathrm{~mm} /$ year in winter and the temperature in winter (January) ranged between 8 and $18^{\circ} \mathrm{C}$ but in summer (August) the average increase to $22-30^{\circ} \mathrm{C}$ (Rohling et al., 2009).

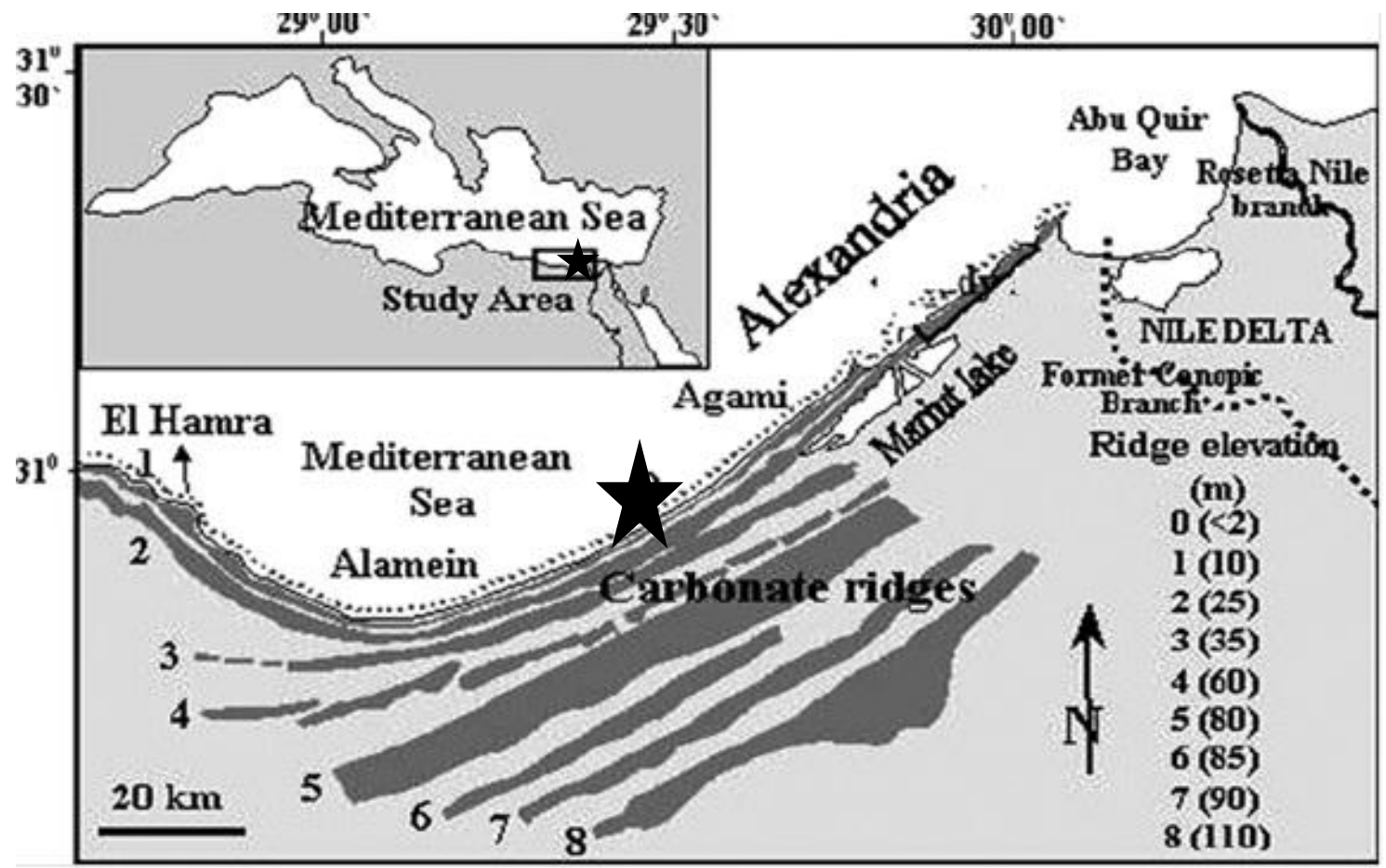

Fig. 1. Location map of the study area in the Mediterranean coastal region is presented by star (After Frithy et al. development, 2004). 


\section{Habitats description}

After visiting habitats for several times at the western desert of Egypt that extend from Burg El-Arab to Omayed city (80km from Alexandria) the studied species appeared only in the slopes (north, north-east and north-west) of Abu sir ridge and disappeared at the plateau and the south slope in addition to the other calcareous sites where the plant was recorded previously (Ayyad \& Ammar, 1974). The species was also recorded at both north and south slopes of the sand dunes in Burg El-Arab area. Therefore, the data of vegetation analysis and environmental factors were detected at the different sites where the studied when species were present (Plate 1). The study was carried out at the flowering stage of T. capitatus (April to May 2018). Plant density, frequency, abundance, canopy cover, associated species including the nearest and neighbor plant species for $T$. capitatus and the canopy diameter of T. capitatus (largest and smallest) were directly recorded in the field using quadrates and transects method (Mannetje, 1978). Five stands (30 X 50m) were chosen in each habitat and sample size were determined by minimum area and vegetation surveyed by using 50 quadrates in each stand and the cover determination was carried out along five transects $(50 \mathrm{~m})$ in each stand. Vegetation type and life form spectrum for each recorded species in $T$. capitatus communities were identified according to Raunkiaer (1937). Plant nomenclature is according to Täckholm (1974) and Boulos (2009). Plant distributions pattern was determined by index of Hopkins (Moghaddam, 2001):

$$
\mathbf{I h}=\Sigma\left(\mathrm{X}_{\mathrm{i}}\right)^{2} / \Sigma\left(\mathrm{X}_{\mathrm{i}}\right)^{2}+\Sigma\left(\mathrm{r}_{\mathrm{i}}\right)^{2}
$$

where Ih is Hopkins index, $\mathrm{X}_{\mathrm{i}}$ is distance of nearest plant to the random point and $\mathrm{r}_{\mathrm{i}}$ is distance of nearest neighboring plant.

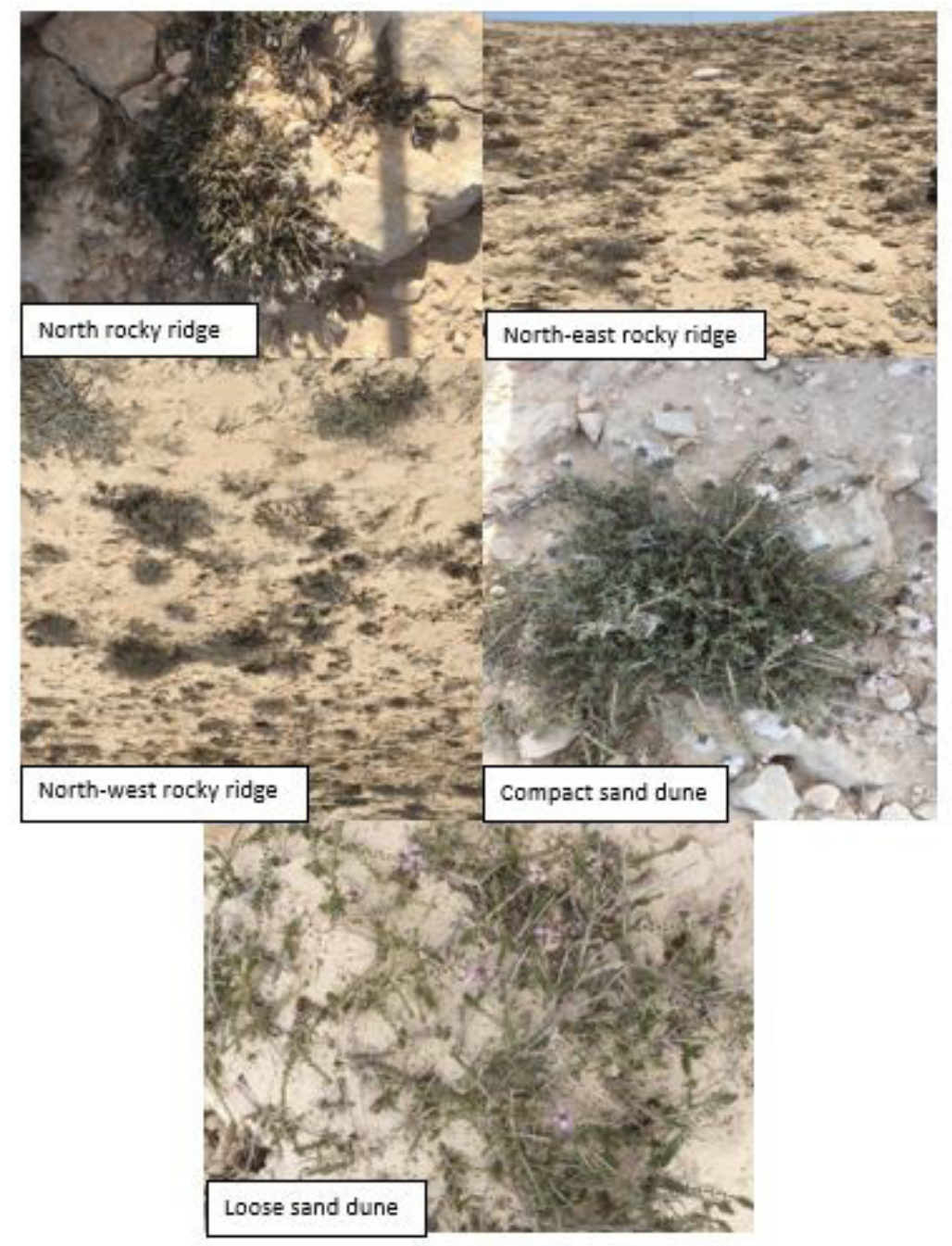

Plate 1. The distribution pattern of Thymus capitotus communities in the different sites of the study area. 


\section{Soil analysis}

Three soil samples were collected from each location from the depth ranged from $0-30 \mathrm{~cm}$ which represents different habitats. The hydrometer method was applied to determine soil texture (Allen et al., 1989). The organic matter was determined by wet oxidation according to Black (1965). Soil paste extract was prepared according to Richards (1954) for measurement of $\mathrm{pH}$, electrical conductivity (EC) as $(\mathrm{ds} / \mathrm{m})$, soluble cations $\left(\mathrm{Ca}^{++}, \mathrm{Mg}^{++} \mathrm{Na}^{+}\right.$, $\left.\mathrm{K}^{+}\right)$and anions $\left(\mathrm{CO}_{3}^{-}, \mathrm{HCO}_{3}^{-}, \mathrm{Cl}^{-}, \mathrm{SO}_{4}^{-}\right)$. The $\mathrm{pH}$ of each sample was determined by $\mathrm{pH}$ meter (Hanna instruments-HI 2211) with a glass electrode. The electrical conductivity of each soil sample was determined using an electrical conductivity meter (WTW series-inoLab-Cond-720). Microelement content ( $\mathrm{Cu}, \mathrm{Fe}, \mathrm{Mn}, \mathrm{Cd})$ was analyzed according to Lindsay \& Norvell (1978) using atomic absorption spectrophotometry (AAS) equipped with flame and graphite furnace. Calcium carbonate assayed by Calcimeter method according to Black (1965).

\section{Statistical application}

Correlation coefficient between vegetation analysis and soil characters in the study area in addition to standard deviation of soil analysis was done using SPSS software (Kirkpatrick \& Feeney, 2013).

\section{Results}

\section{Vegetation parameters}

The assessment of the biological features of a species needs to understand the distribution pattern of species in niches which is the most part of its life cycle and also critical for the wildlife management. The habitat of species information includes edaphic, bioclimatic, topographic and biotic characteristics of a specific area. This information describes entirety of the biotic and abiotic factors required by plant species. The Flora of study area is attained with 22 species ( $T$. capitatus +21 associated species) belonging to 16 different families. Vegetation survey showed that $T$. capitatus is a dominant perennial subshrub species associated with different life forms of species in five selected locations (Table 1). Family Astraceae and Chenopodiaceae have largest number of species ( 3 species in each one) followed by Family Leguminosae (2 species). The other recorded families in Table 1 include one species only. This table also showed that some associated species are dominant in all locations but the other species are restricted to specific location.
With regard to the type of plant growth, the major type of growth was perennial subshrub which represented by $47.62 \%$. The perennial herb attained with the lowest percentage (14.29\%) and does not exceed three species (Fig. 2). The life form spectrum of the recorded species according to Raunkiaer (1937) classification was represented in Table 1. The relative percentage of each life form was presented in Fig. 3 and it show that Chaemephytes $(\mathrm{Ch})$ were the most frequent life form plants constituted by 9 species, followed by Hemicryptophytes (He) with 4 species, Therophytes (Th) and Phanerophytes ( $\mathrm{Ph}) 3$ species for each and Cryptophytes (Cr) with 2 species with different percentages. Echinops spinosus, Helianthemum lipii, Gymnocarpos decandrum, Pituranthos tortuosa and Thymelaea hirsuta were recorded in all five locations of the study area while Noaea mucronata, Anabasis articulate, Asphodelus microcarpus, Globularia arabica and Dactylis glomerata only in 3 locations but the other plant species present in 2 or one location (Table 1 and Fig. 4).

Table 2 showed that the vegetation analysis of $T$. capitatus in the selected area in the Mediterranean coastal region of Egypt. This plant is distributed in different slopes of calcareous Abou-Sir ridge (north, north-east and north-west) and in the north and south direction of sand dune (consolidated and loose). The field observation showed the disappearance of this species in the top and south slope of the ridge. The highest values of density and frequency were recorded in rocky north-west slope but the minimum was in the loose sand dune (south direction). However, the highest canopy cover and mean canopy diameter were recorded in the consolidated sand dune and the minimum values were in the rocky north slope of the ridge. The highest abundance (appearance density) was recorded in rocky north-east slope of ridge while the lowest value was in consolidated sand dune.

The arrangement of the nearest associated plant species to T. capitatus was presented according to the distance between study species and associated one with the lowest distance while the neighbor species represented by the distance between the study species and the closest species to the nearest one (Table 3). The present study showed that Globularia arabica, Pituranthos tortosus and Noaea mucronata are the most nearst species to study species in the different slopes of the ridge (rocky-north, rocky north-west and rocky north- 
east) respectively, while Helianthemum lipii and Pituranthos tortosus were in the consolidated and loose sand dune. The most neighbor plant species in the study area are Globularia arabica, Noaea muconata in the rocky ridge and Gymnocarpos decandrum and Pituranthus tortousus were in the sand dune. Distribution patterns show the spatial relationship between members of a population within a habitat. The distribution of species into clumped, uniform, or random depends on the index value of Hopkin. As Hopkin approaches 0 it indicates a more "uniform" pattern. As Hopkin approaches 1 it indicates a more "clustered" pattern. A value of 0.5 is considered random. The present results showed that distribution pattern of T. capitatus species are uniform (Table 3). The uniform pattern is the common pattern in the desert area.

The physical and chemical characters of the soil

The physical and chemical analysis of the collected soil samples from the different locations of T. capitatus communities have been presented in Table 4. Generally, the result illustrated that the soil in the most studied locations are sandy loam or sandy except location 3 was loamy sand and $\mathrm{pH}$ in all locations were slightly basic. The electrical conductivity which indicates that the soil salinity was higher in rocky than sandy locations; also, the most studied anions $\left(\mathrm{Ca}^{++}, \mathrm{Mg}^{++}, \mathrm{Na}^{+}\right)$and cations $\left(\mathrm{Cl}^{-}, \mathrm{SO}_{4}^{-}, \mathrm{HCO}_{3}\right)$ were higher in rocky than that in sandy locations. However, the opposite trend for $\mathrm{CO}_{3}^{-}$(meq/L) and $\mathrm{CaCO}_{3} \%$ were recorded in studied locations. Organic matter and studied heavy metals such as $\mathrm{Cu}, \mathrm{Fe}, \mathrm{Mn}, \mathrm{Zn}$ in rocky were higher than in sandy locations. Cd metal was not detected in the sites selected in sand dunes and the content of the rocky ridge sites was trace. The soil texture in the different locations effect on the soil moisture percentages whereas the sand dune habitats (sandy soil) attained with the lowest content of soil moisture.

TABLE 1. List of the associated species in $T$. capitatus community recorded in the study area with their families, vegetation type, life form and its locations.

\begin{tabular}{|c|c|c|c|c|}
\hline Family & Species & Vegetation type & Life form & Locations \\
\hline \multirow[t]{3}{*}{ Compositae } & - Echinops spinosus & Perennial subshrub & $\mathrm{Ch}$ & $1,2,3,4,5$ \\
\hline & - Jasonia candicans & Perennial shrub & $\mathrm{Ph}$ & 4 \\
\hline & - Aegialophila pumila & Perennial subshrub & $\mathrm{He}$ & 5 \\
\hline Cistaceae & Helianthemum lipii & Perennial subshrub & $\mathrm{Ch}$ & $1,2,3,4,5$ \\
\hline Caryophyllaceae & Gymnocarpos decandrum & Perennial subshrub & $\mathrm{Ch}$ & $1,2,3,4,5$ \\
\hline \multirow[t]{3}{*}{ Chenopodiaceae } & - Noaea mucronata & Perennial subshrub & $\mathrm{Ch}$ & $1,2,3$ \\
\hline & - Anabasis articulate & Perennial shrub & $\mathrm{Ph}$ & $1,2,3$ \\
\hline & - Suaeda vermiculata & Perennial shrub & $\mathrm{Ch}$ & 2 \\
\hline Umbelliferae & Pituranthos tortuosa & Perennial subshrub & $\mathrm{Ch}$ & $1,2,3,4,5$ \\
\hline Boraginaceae & Echium setosum & Annual & $\mathrm{He}$ & 1 \\
\hline Liliaceae & Asphodelus microcarpus & Perennial herb & $\mathrm{Cr}$ & $1,2,3$ \\
\hline Globulariaceae & Globularia arabica & Perennial subshrub & $\mathrm{Ch}$ & $1,2,3$ \\
\hline Thymelaeaceae & Thymelaea hirsuta & Perennial shrub & $\mathrm{Ph}$ & $1,2,3,4,5$ \\
\hline Gramineae & Dactylis glomerata & Perennial herbs & $\mathrm{Cr}$ & $1,2,3$ \\
\hline Rubiaceae & Crucianella maritime & Perennial subshrub & $\mathrm{Ch}$ & 4,5 \\
\hline Labiatae & Teucrium polium & Perennial subshrub & $\mathrm{He}$ & 4,3 \\
\hline Resedaceae & Reseda alba & Annual & $\mathrm{Th}$ & 4,5 \\
\hline \multirow[t]{2}{*}{ Leguminosae } & - Ononis vaginalis & Perennial subshrub & $\mathrm{Ch}$ & 5 \\
\hline & - Lotus creticus & Perennial herbs & $\mathrm{He}$ & 5 \\
\hline Ranunculaceae & Delphinium peregrinum & Annual & $\mathrm{Th}$ & 2 \\
\hline Papaveraceae & Roemeria hybrid & Annual & $\mathrm{Th}$ & 2 \\
\hline
\end{tabular}

1. Rocky- north, 2. Rocky north west, 3. Rocky north east, 4. Consolidated sand dune, 5. Loose sand dune. 

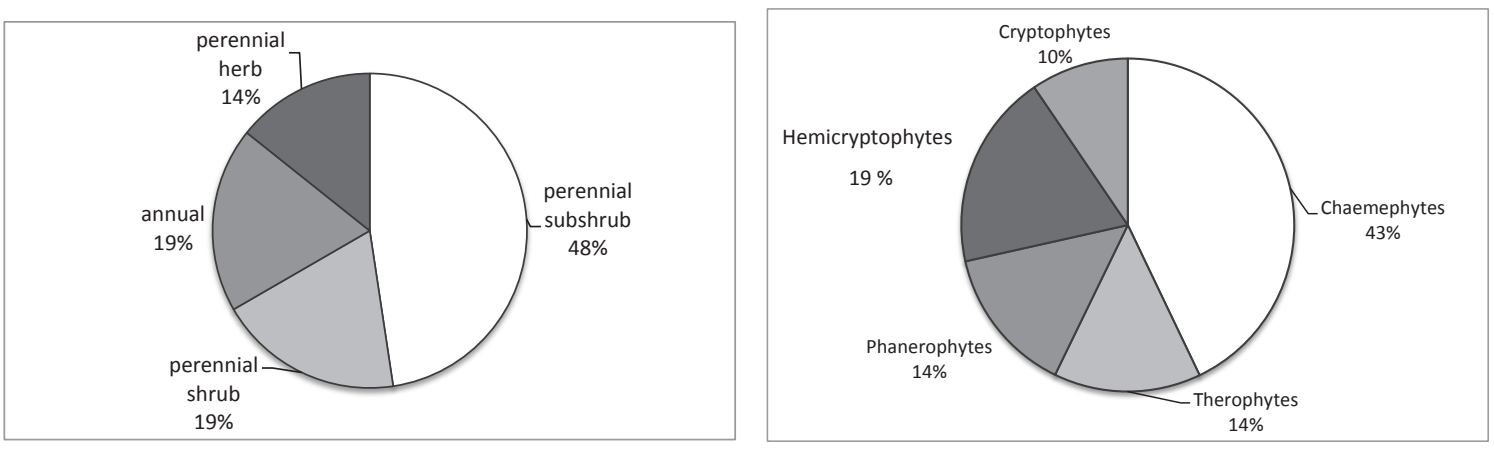

Fig. 2. Vegetation type of the associated species with distribution of $T$. capitatus in the study area.

Fig. 3. Life form spectrum of the associated species with the distribution of $T$.capitatus in the study area.

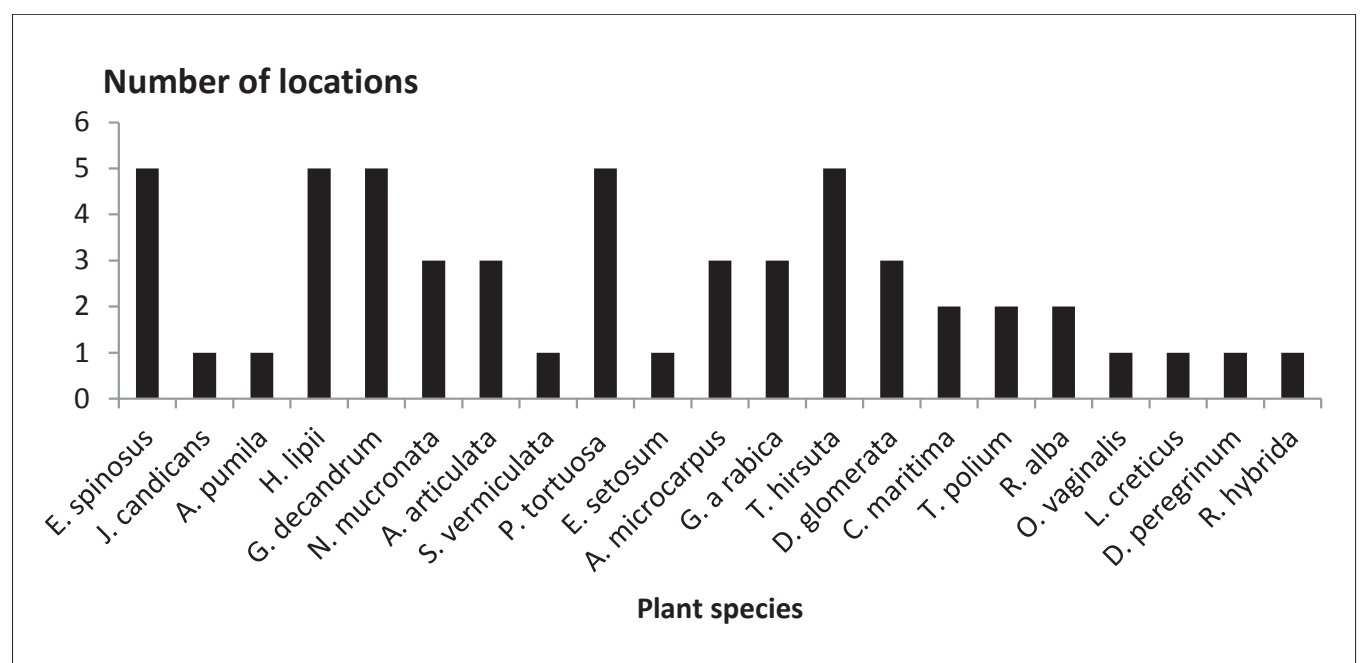

Fig. 4. The number of locations of associated species recorded with the distribution of T.capitatus in the study area.

TABLE 2. The vegetative characteristics of $T$. capitatus in the study area.

\begin{tabular}{lccccccc}
\hline \multirow{2}{*}{ Location } & \multirow{2}{*}{$\begin{array}{c}\text { AD } \\
\text { No. }\end{array}$} & F. $(\%)$ & C.(\%) & Ab. & \multicolumn{3}{c}{ CD (cm) } \\
\cline { 6 - 8 } & 2.54 & $87.77 \%$ & $9.78 \%$ & 2.97 & 25 & 150 & 86.82 \\
2 & 2.73 & $93.33 \%$ & $14.83 \%$ & 2.93 & 28 & 205 & 88.30 \\
3 & 2.31 & $75.57 \%$ & $12.57 \%$ & 3.03 & 30 & 150 & 86.93 \\
4 & 1.33 & $86.67 \%$ & $25.07 \%$ & 1.54 & 79 & 400 & 205.75 \\
5 & 1.18 & $71.67 \%$ & $17.1 \%$ & 1.60 & 38 & 200 & 92.38 \\
\hline
\end{tabular}

$\mathrm{AD}=$ Absolute density, $\mathrm{F}=$ Absolute frequency, $\mathrm{C}=$ Absolute cover, $\mathrm{Ab}=$ Abundance and $\mathrm{CD}=$ Canopy diameter.

1. Rocky- north, 2. Rocky north west, 3. Rocky north east, 4. Consolidated sand dune, 5. Loose sand dune.

TABLE 3. The arrangement of the nearest and neighbor associated species to T. capitatus and the values of Hopkin index $\left(\mathbf{I}_{\mathrm{h}}\right)$.

\begin{tabular}{lccc}
\hline Locations & Nearest species of Thymus capitatus & Neighbor species of Thymus capitatus & $\mathbf{I}_{\mathbf{h}}$ \\
\hline 1 & Globularia $>$ Noaea $>$ Pituranthos & Globularia $>$ Noaea $>$ Echinops & 0.185 \\
2 & Pituranthos $>$ Helianthemum. $>$ Noaea & Noaea $>$ Pituranthos $=$ Helianthemum. & 0.225 \\
3 & Noaea & Globularia $>$ Noaea & 0.181 \\
4 & Helianthemum. $>$ Pituranthos $>$ Crucianella & Gymnocarpos $>$ Helianthemum. $=$ Crucianella & 0.219 \\
5 & Pituranthos $>$ Helianthemum. $=$ Gymnocarpos & Pituranthos $>$ Crucianella $=$ Echinops & 0.229 \\
\hline
\end{tabular}

1. Rocky- north, 2. Rocky north west, 3. Rocky north east, 4. Consolidated sand dune, 5. Loose sand dune. 
TABLE 4. The soil analysis of different locations at habitats of $T$. capitatus.

\begin{tabular}{|c|c|c|c|c|c|}
\hline \multirow{2}{*}{ Soil parameters } & \multicolumn{5}{|c|}{ Locations } \\
\hline & 1 & 2 & 3 & 4 & 5 \\
\hline Sand $\%$ & $77.67 \pm 2.52$ & $80.67 \pm 2.52$ & $82.00 \pm 2.65$ & $94.00 \pm 1.73$ & $94.33 \pm 1.15$ \\
\hline Slit \% & $7.00 \pm 1.73$ & $8.33 \pm 0.58$ & $7.67 \pm 0.58$ & $4.33 \pm 0.58$ & $4.33 \pm 0.58$ \\
\hline Clay \% & $15.33 \pm 2.08$ & $11.0 \pm 1.0$ & $10.33 \pm 1.53$ & $1.67 \pm 0.58$ & $1.33 \pm 0.58$ \\
\hline $\mathrm{EC}(\mathrm{ds} / \mathrm{m})$ & $3.06 \pm 0.52$ & $2.42 \pm 0.28$ & $2.05 \pm 0.18$ & $1.92 \pm 0.04$ & $1.22 \pm 0.11$ \\
\hline $\mathrm{Ca}^{++}(\mathrm{meq} / \mathrm{L})$ & $10.36 \pm 1.40$ & $6.31 \pm 0.14$ & $5.73 \pm 0.60$ & $3.35 \pm 0.30$ & $2.17 \pm 0.24$ \\
\hline $\mathrm{Mg}^{++}(\mathrm{meq} / \mathrm{L})$ & $4.15 \pm 1.01$ & $2.73 \pm 0.27$ & $2.18 \pm 0.07$ & $2.27 \pm 0.37$ & $1.50 \pm 0.14$ \\
\hline $\mathrm{Na}^{+}(\mathrm{meq} / \mathrm{L})$ & $14.28 \pm 1.39$ & $13.82 \pm 1.02$ & $11.92 \pm 1.49$ & $10.81 \pm 1.34$ & $9.03 \pm 0.77$ \\
\hline $\mathrm{K}^{+}(\mathrm{meq} / \mathrm{L})$ & $1.40 \pm 0.06$ & $1.46 \pm 0.10$ & $1.16 \pm 0.09$ & $1.76 \pm 0.56$ & $1.18 \pm 0.13$ \\
\hline $\mathrm{CO}_{3}^{---}(\mathrm{meq} / \mathrm{L})$ & 0.00 & 0.00 & 0.00 & 0.30 & 0.40 \\
\hline $\mathrm{HCO}_{3}^{-}(\mathrm{meq} / \mathrm{L})$ & $7.97 \pm 1.24$ & $6.27 \pm 0.76$ & $5.34 \pm 1.25$ & $3.44 \pm 0.33$ & $2.65 \pm 0.35$ \\
\hline $\mathrm{Cl}^{-}(\mathrm{meq} / \mathrm{L})$ & $13.36 \pm 0.67$ & $15.31 \pm 0.68$ & $12.13 \pm 0.90$ & $11.15 \pm 0.34$ & $9.03 \pm 0.91$ \\
\hline $\mathrm{SO}_{4}^{--}(\mathrm{meq} / \mathrm{L})$ & $7.33 \pm 1.28$ & $5.84 \pm 1.20$ & $5.89 \pm 5.89$ & $4.26 \pm 0.46$ & $2.62 \pm 0.34$ \\
\hline $\mathrm{CaCO}_{3} \%$ & $60.06 \pm 4.41$ & $52.71 \pm 2.24$ & $53.92 \pm 1.39$ & $90.69 \pm 1.23$ & $82.50 \pm 1.03$ \\
\hline O.M \% & $2.98 \pm 0.40$ & $2.50 \pm 0.24$ & $1.92 \pm 0.22$ & $0.71 \pm 0.03$ & $0.47 \pm 0.05$ \\
\hline $\mathrm{Cu}(\mathrm{mg} / \mathrm{kg})$ & $0.83 \pm 0.02$ & $0.87 \pm 0.01$ & $0.86 \pm 0.01$ & $0.0 \pm 0.0$ & $0.0 \pm 0.0$ \\
\hline $\mathrm{Fe}(\mathrm{mg} / \mathrm{kg})$ & $9.90 \pm 0.29$ & $11.46 \pm 1.05$ & $7.58 \pm 0.26$ & $2.67 \pm 0.21$ & $1.64 \pm 0.11$ \\
\hline Mn (mg/kg) & $24.10 \pm 1.70$ & $20.73 \pm 0.46$ & $21.06 \pm 2.13$ & $1.91 \pm 0.08$ & $1.33 \pm 0.25$ \\
\hline Zn (mg/kg) & $2.38 \pm 0.12$ & $3.37 \pm 0.38$ & $2.07 \pm 0.24$ & $0.55 \pm 0.04$ & $0.51 \pm 0.01$ \\
\hline $\mathrm{Cd}(\mathrm{mg} / \mathrm{kg})$ & 0.003 & 0.001 & 0.012 & 0.000 & 0.000 \\
\hline Soil moist \% & $1.84 \pm 0.28$ & $1.54 \pm 0.25$ & $1.69 \pm 0.44$ & $1.39 \pm 0.18$ & $1.05 \pm 0.17$ \\
\hline $\mathrm{pH}$ & 7.63 & 8.01 & 7.88 & 8.03 & 8.06 \\
\hline
\end{tabular}

1. Rocky- north, 2. Rocky north west, 3. Rocky north east, 4. Consolidated sand dune, 5. Loose sand dune.

Correlation between vegetation and soil analysis

The statistical data in Table 5 showed that densities and canopy diameter of studied species correlated significantly with the most soil characters but $\mathrm{K}^{+}$correlated significantly only with canopy diameter. Frequency \% correlated significantly with both EC and chloride while cover $\%$ only correlated significantly with sand \%.

\section{Discussion}

The present study focused on the habitat characters and distribution mode of medicinal plant $T$. capitatus to make recommendations concerning the conservation of this species community from different threats. Medicinal plants refer to species having aromatic compounds, and culinary importance. The active constituents in medicinal plants with their distribution and utilization in folk medicine at the Mediterranean region of Egypt have attracted many ecologists, taxonomists and phytochemists. Special distribution of plant species and communities along a small geographic area in the desert ecosystem is related to heterogenous topography and landform pattern (Harness \& West, 1973). The flora of the western Mediterranean region is subject to threats that cause declines in the number of species, population number and size. So, there are many medicinal plant species that disappeared such as $T$. capitatus which missed in some sites due to different human activities that led to the destruction of natural habitats or habitat loss. Mosallam et al. (2017) also indicated that $T$. capitatus is also an endangered species in Al-Jabal Al-Akhdar, Lybia. A lot of disturbances due to human impact are recorded throughout the western Mediterranean region, including over-collection, over-cutting for fuel wood, land conversion (construction of new settlements, infrastructure, cultivation areas and digging new wells), other land use, tourism and solid waste (due to urbanization and tourism activities). 
TABLE 5. Correlation levels between vegetation characters of $T$. capitatus and different soil parameters $(\mathrm{n}=15)$.

\begin{tabular}{|c|c|c|c|c|c|c|c|c|}
\hline \multirow{3}{*}{ Soil parameters } & \multicolumn{8}{|c|}{ Vegetation analysis } \\
\hline & \multicolumn{2}{|c|}{ Density } & \multicolumn{2}{|c|}{ Frequency (\%) } & \multicolumn{2}{|c|}{ Cover $(\%)$} & \multicolumn{2}{|c|}{$\begin{array}{c}\text { Canopy diameter } \\
(\mathrm{cm})\end{array}$} \\
\hline & $\mathbf{r}$ & $\mathbf{p}$ & $\mathbf{R}$ & $\mathbf{P}$ & $\mathbf{R}$ & $\mathbf{p}$ & $\mathbf{R}$ & p \\
\hline Sand \% & $-0.536^{*}$ & $0.040^{*}$ & -0.275 & 0.322 & $0.589^{*}$ & $0.021^{*}$ & $0.632^{*}$ & $0.012^{*}$ \\
\hline Slit \% & $0.539^{*}$ & $0.038^{*}$ & 0.129 & 0.648 & -0.406 & 0.133 & $-0.538^{*}$ & $0.039^{*}$ \\
\hline Clay\% & $0.716^{*}$ & $0.003^{*}$ & 0.348 & 0.204 & -0.424 & 0.115 & $-0.581^{*}$ & $0.023^{*}$ \\
\hline $\mathrm{EC}(\mathrm{ds} / \mathrm{m})$ & $0.700^{*}$ & $0.004^{*}$ & $0.567^{*}$ & $0.027^{*}$ & -0.129 & 0.648 & -0.186 & 0.508 \\
\hline $\mathrm{Ca}^{++}(\mathrm{meq} / \mathrm{L})$ & $0.593^{*}$ & $0.020^{*}$ & 0.386 & 0.155 & -0.438 & 0.102 & -0.423 & 0.116 \\
\hline $\mathrm{Mg}^{++}(\mathrm{meq} / \mathrm{L})$ & 0.458 & 0.086 & 0.483 & 0.068 & -0.329 & 0.231 & -0.213 & 0.446 \\
\hline $\mathrm{Na}^{+}(\mathrm{meq} / \mathrm{L})$ & $0.532^{*}$ & $0.041^{*}$ & 0.510 & 0.052 & -0.371 & 0.173 & -0.343 & 0.211 \\
\hline $\mathrm{K}^{+}(\mathrm{meq} / \mathrm{L})$ & 0.108 & 0.700 & 0.481 & 0.070 & 0.311 & 0.259 & $0.599^{*}$ & $0.018^{*}$ \\
\hline $\mathrm{HCO}_{3}^{-}(\mathrm{meq} / \mathrm{L})$ & $0.539^{*}$ & $0.038^{*}$ & 0.342 & 0.212 & -0.416 & 0.123 & -0.449 & 0.093 \\
\hline $\mathrm{Cl}^{-}(\mathrm{meq} / \mathrm{L})$ & $0.656^{*}$ & $0.008^{*}$ & $0.540^{*}$ & $0.038^{*}$ & -0.132 & 0.639 & -0.249 & 0.371 \\
\hline $\mathrm{SO}^{--}(\mathrm{meq} / \mathrm{L})$ & $0.563^{*}$ & $0.029^{*}$ & 0.296 & 0.284 & -0.301 & 0.275 & -0.295 & 0.285 \\
\hline $\mathrm{CaCO}_{3} \%$ & $-0.640^{*}$ & $0.010^{*}$ & -0.193 & 0.492 & 0.482 & 0.069 & $0.732^{*}$ & $0.002^{*}$ \\
\hline O.M \% & $0.670^{*}$ & $0.006^{*}$ & 0.393 & 0.148 & -0.450 & 0.092 & $-0.555^{*}$ & $0.032^{*}$ \\
\hline $\mathrm{Cu}(\mathrm{mg} / \mathrm{kg})$ & $0.644^{*}$ & $0.010^{*}$ & 0.253 & 0.363 & -0.495 & 0.061 & $-0.651^{*}$ & $0.009^{*}$ \\
\hline $\mathrm{Fe}(\mathrm{mg} / \mathrm{kg})$ & $0.708^{*}$ & $0.003^{*}$ & 0.457 & 0.087 & -0.402 & 0.137 & $-0.526^{*}$ & $0.044^{*}$ \\
\hline $\mathrm{Mn}(\mathrm{mg} / \mathrm{kg})$ & $0.621^{*}$ & $0.014^{*}$ & 0.233 & 0.404 & -0.504 & 0.056 & $-0.642^{*}$ & $0.010^{*}$ \\
\hline $\mathrm{Zn}(\mathrm{mg} / \mathrm{kg})$ & $0.652^{*}$ & $0.008^{*}$ & 0.430 & 0.109 & -0.412 & 0.127 & $-0.556^{*}$ & $0.031^{*}$ \\
\hline Soil moist \% & $0.540^{*}$ & $0.038^{*}$ & 0.139 & 0.622 & -0.191 & 0.495 & -0.237 & 0.395 \\
\hline
\end{tabular}

The results of the vegetation survey of the present study identified 21 plant species with $T$. capitatus during the study period in the chosen stands. The identified species belonged to 16 families. Compositae, Chenopodiaceae, Leguminosae and Labiatae are represented by the highest number of species respectively. Among the recorded species in this region, some were extremely rare and poorly known and their results reveal that some of these plants were recorded in a single habitat (Jasonia candicans, Aegialophila pumila, Suaeda vermiculaata, Echium setosum, Ononis vaginalis, Lotus creticus, Delphinium peregrinum and Roemeria hybrid), while others were recorded in all selected habitats in the studied area of T. capitatus community (Echinops spinosus, Helianthemum lipii, Gymnocarpos decandrum, Pituranthos tortuosa and Thymelaea hirsute). The rest species in the study area were recorded in 3 or 2 habitats. Dispersion or distribution patterns show the spatial relationship between members of a population within a habitat. The distribution of species into clumped, uniform, or random depends on different abiotic and biotic factors (Moghaddam, 2001). The index data of Hopkin (approximately 0) indicate that the distribution pattern of T. capitatus species is uniform. Uniform distribution is the most common type of dispersion found in the desert for the presence of resource-deficiency. The life form of desert plants is positive correlated with rainfall, topography and land form (Kassas \& Girgis, 1965 and Orshan, 1986). The present results of the frequency of associated species in T. capitatus communities indicate the absence of negative allelopathic effects between studied species and associated ones.

Soil texture has a large effect on soil moisture and available nutrients to plants (Jafari et al., 2006). The minimum and maximum electrical conductivities are 1.22 and $3.05 \mathrm{ds} / \mathrm{m}$, respectively, indicating that this plant grows in the non-saline soils. The soil $\mathrm{pH}$ values range from 7.63 to 8.06 , which are related to the alkaline class. The solubility of nutrients and their ionic forms is the most important effects of $\mathrm{pH}$ (Ronen, 2007). Some nutrients might become unavailable while others might reach high concentrations leading to deficiency or toxicity, respectively, at different levels of $\mathrm{pH}$ (Ronen, 2007). In our study, $\mathrm{pH}$ range is optimum when calcium carbonate content 
of the soils of $T$. capitatus varies from 50.67$90.10 \%$. It can be seen that this plant generally prefers calcareous soils but the increases in $\mathrm{CaCO}_{3}$ led to the decrease in plant density such as in sand dune habitats. Average K values were 108$210 \mathrm{ppm}$ in the area. Normal values of $\mathrm{K}$ in soil lie between 130 and 580ppm and the average value is $355 \mathrm{ppm}$ (Eskin et al., 2013). Therefore, it can be concluded that $\mathrm{K}$ levels in the soils of T. capitatus are lower than the average. The average of soil $\mathrm{Na}$ in $\mathrm{mmol} / \mathrm{L}$ was measured as 8.7-14.73 $(\mathrm{mmol} / \mathrm{L})$ in the habitats of $T$. capitatus. These values are lower than the normal limits lying around 46 $\mathrm{mmol} / \mathrm{L}$ (Eskin et al., 2013).

Soil and vegetation are closely related, so any suggestion for reform in the habitat should consider the soil characteristics. Having knowledge about soil properties of each species has an effective role in suggesting suitable species to the soil conditions in the same areas (Jafari et al., 2006). Soil pH is a major factor inducing the availability of elements in the soil for plant uptake (Marschner, 1995). Also, Tekdal et al. (2018) reported that $\mathrm{pH}$ value is crucial for biological activity, nutrient uptake and soil structure. The present data indicated that the distribution of Thymus communities in arid ecosystems is controlled by physiographic features, edaphic conditions, and topographical irregularities including direction of slopes which all act through modifying the amount of available moisture.

The statistical data indicated that densities and canopy diameters of studied species correlated significantly with most of the soil characters except $\mathrm{K}^{+}$that correlated significantly only with canopy diameter. This indicates an important role of $\mathrm{K}^{+}$in the $T$. Capitatus growth. Hasanuzzaman et al. (2018) indicated that $\mathrm{K}^{+}$ is one of the vital elements required for plant growth and physiology such as photosynthesis and stomatal regulation. The highest diameter for studied species was recorded in the habitats with a high positive significant $\mathrm{K}^{+}$content even though the density was low and $\mathrm{CaCO}_{3}$ recorded the highest content. The rocky ridges with different directions showed both the highest plant densities and the lowest sand \% when compared with other habitats. So, this data indicates that the soil characters controlled the distribution and morphological features of the studied species. Asaadi \& Yazdi (2016) confirmed these results on Thymus transcaspicus.
Hence, we can conclude that $T$. capitatus generally prefers the climate conditions with moderate temperature and are adapted to low rainfall. It prefers the soil texture of the region to be sandy loam or loamy sand more than sandy. T. capitatus grows in the non- saline soils and prefers the calcareous soils with a limited average amount of $\mathrm{CaCO}_{3}$ and adequate amounts of $\mathrm{K}^{+}$. Previously, Shaltout (2002) concluded that the rockiest sites in the inland ridges habitat with also the lowest moisture availability are dominated by communities of $T$. capitatus and Globularia arabica. However, the present study indicates that the studied species disappeared in inland ridges. In order to conserve the biota of this ecosystem, particularly the flora and vegetation including the unique, endemic and near endemic species, from the results of the present study, destruction of the coastal dunes and ridges for building the summer resorts and any other land uses along the Mediterranean coast should stop.

\section{$\underline{\text { References }}$}

Abdelraouf, A.M., Mohamed, S.Z. and Najmah, R.A. (2015) Autecology for two threatened species Teucrium polium and Verbascum sinaiticum growing in south sinai for conservation approach. Journal of Global Biosciences, 4, 3121-3139.

Abdel-Razik, M., Abdel-Aziz, M. and Ayyad, M. (1984) Multivariate analysis of vegetational variation in different habitats at Omayed (Egypt). Vegetatio, 57, 167-175.

Allen, S., Grimshaw, H.M., Parkinson, J.A., Quarmbym, C., Ducommun, A. and Matthey, W. (1989) "Chemical Analysis of Ecological Materials". $2^{\text {nd }}$ ed., Blackwell Scientific Publications, London. $565 \mathrm{p}$.

Asaadi, A.M. and Yazdi. A.K. (2016) The autecological characteristics of Thymus transcaspicus Klokov medicinal plant in North East Rangelands of Iran. Journal of Medicinal Plants Studies, 4, 85-90.

Ayyad, M.A. and Ammar, M.Y. (1974) Vegetation and environment of the western Mediterranean coastal land of Egypt: II. The habitat of inland ridges. $J$ Ecol. 62, 439-56.

Black, C.A. (1965) "Methods of Soil Analysis. Chemical and Microbiological Properties Part II". American 
Society of Agricultural Inc., 1044p.

Boulos, L. (2009) "Flora of Egypt: Checklist", Revised Annotated ed. Al Hadara Publishing, Cairo, 410p.

Bounatirou, S., Smiti, S., Miguel, M.G., Faleiro, L., Rejeb, M.N., Neffati, M., Costa, M.M., Figueiredo, A.C., Barroso, J.G. and Pedro, L.G. (2007) Chemical composition, antioxidant and antibacterial activities of the essential oils isolated from Tunisian Thymus capitatus Hoff. Food Chemistry, 105, 146-155.

Dzamic, A.M., Nikolic, B.J., Giweli, A.A, MitićĆulafić, D.S., Soković, M.D. and Ristić, M.S. (2015) Libyan Thymus capitatus essential oil: Antioxidant, antimicrobial, cytotoxic and colon pathogen adhesion-inhibition properties. Journal of Applied Microbiology, 119, 389-399.

Enright, N.J, Miller, B.P. and Akhter, R. (2005) Desert vegetation and vegetation-environment relationships in Kirthar National Park, Sindh, Pakistan. J. Arid Environment, 61, 397-418.

Eskin, B., Ozyigit, I., Dogan, I., Altay, V., Demir, G. and Serin, M. (2013) Germination physiology and autecology of Centaurea kilaea Boiss. from Turkey. Sains Malaysiana, 42, 1473-1482.

Frithy, O.E., Iskander, M.M. and Badr, A.A. (2004) Effect of shoreline and bedrock irregularities on the morphodynamics of the Alexandria cell, Egypt. Geo-Marlett. 24, 195-211.

Gholijani, N., Gharagozloo, M., Farjadian, S. and Amirghofran, Z. (2015) Modulatory effects of thymol and carvacrol on inflammatory transcription factors in lipopolysaccharide-treated macrophages. J. Immunotoxicology, 27, 1-8.

Harness, R.O. and West, N.E. (1973) Vegetation of the national reactor testing station, southeastern. Idaho- Northwest Sci. 45, 30-43.

Hasanuzzaman, M., BorhannuddinBhuyan, M.H.M., Nahar, K., Shahadat Hossain, M.D., Al Mahmud, J., Shahadat Hossen, M.D., Abdul Awal, C.M. and Moumita Masayuki, F. (2018) Potassium: A vital regulator of plant responses and tolerance to abiotic stresses. Agronomy, 31, 1-29.

Hedhilia, L., Romdhane, M., Planche, H. and Abderrabba, M. (2005) Towards gas chromatography-mass spectrometry coupling protocols for both identifying and quantification essential oils of Thymus capitatus Hoff. $J$. Chromatography, 1064, 129-134.

Imelouane, B., Amhamdi, H., Wathelet, J.P., Ankit, M., Khedid, K. and El Bachiri, A. (2009) Chemical composition and antimicrobial activity of the essential oil of thyme (Thymus vulgaris) from Eastern Morocco. International J. Agriculture and Biology, 11, 205-208.

Ismaili, H., Milella, L., Frih-Tetouani, S. and Ilidrissi, A. (2004) In vivo topical anti-inflammatory and in vitro antioxidant activities of two extracts of Thymus satureioides leaves. J. Ethnopharmacology, 91, 31-36.

Jafari, M., ZareChahouki, M.A., Tavili, A. and Kohandel, A. (2006) Soil-vegetation relationships in rangelands of Qom province. J. Pajouhesh \& Sazandegi, 73, 110-116.

Kassas, M. and Girgis, W.A. (1965) Habitat and plant communities in the Egyptian desert. VI. The units of a desert ecosystem. J. Ecology, 53, 715-728.

Kirkpatrick, L.A. and Feeney, B.C. (2013) A simple guide to IBM SPSS statistics for version 20.0. Student ed. Belmont, Calif.: Wadsworth, Cengage Learning.

Lindsay, W.L. and Norvell, W.A. (1978) Development of A DTPA micronutrient soil tests for zinc, iron, manganese and cupper. Soil Science American J. 42, 421-428.

Llana-Ruiz-Cabello, M., Guti_errez-Praena, D., Pichardo, S., Maisanaba, S., Puerto, M., Prieto, A.I., Gutiérrez-Praena, D., Jos, A. and Cameán, A.M. (2014) Cytotoxicity and morphological effects induced by carvacrol and thymolon the human cell line Caco-2. Food Chemical Toxicology, 64, 281290.

Mannetje, L. (1978) Measurement of Grassland Vegetation and Animal Production. Commonwealth Agricultural Bureau, Bulletin 52, Hurley, Berkshire, England, 260p.

Marschner, H. (1995) "Mineral Nutrition of Higher Plants", $2^{\text {nd }}$ ed. New York, Academic Press, 889p.

Miceli, A., Negro, C. and Tommasi, L. (2006) Essential oil variability in Thymbra capitata (L.) 
Cav. growing wild in Southren Apulia (Italy). Biochemistry System Ecology, 34, 528-535.

Miguel, M.G., Simoes, M.F., Figueiredo, A.C., Barroso, J.G. and Carvalho, L.M. (2005) Evaluation of the antioxidant activity of Thymus capitatus, Thymus mastichina and Thymus camphoratus essential oil. J. Food Lipids, 12, 181-197.

Moghaddam, M.R. (2001) "Quantitative Plant Ecology". Tehran University Press, 285p.

Mosallam, H.A., Hashim, A.M., Sergiwa, S.S. and Abdalrhim, M.A. (2017) Size distribution of some endangered plant species, Al-Jabal Al-Akhdar, Libya. Egyptian. J. Botany, 57, 181-197.

Orshan, G. (1986) The desert of the Middle East. In: "Ecosystems of the World, 12 B, Hot Deserts and Arid Shrublands". Evenari, M., Noy-Meir, I., Goodall, D.W. (Eds.), Elsevier, Amsterdam.

Raunkiaer, C. (1937) "Plant Life Forms", Clarendon, Oxford, 104p.

Raven, P. (2006) Relationships between Mediterranean floras. In: "Plant Llife in South West Asia", Davis, P.H., Harper, P.C., Hedge, I.C. (Eds.), pp.119-134. Botanical Society of Edinburgh, dinburgh, 1971p.

Richards, L.A. (1954) Diagnosis and improvement of saline and alkali soils. Agric. Res. Service, Agric. U.S. Dept. Agric., Agriculture Handbook No. 60.US Government Printing Office, Washington, D.C. 20402.

Rohling, E.J., Abu-Zied, R., Casford, J.S.L., Hayes, A. and Hoogakker, B.A.A. (2009) The marine environment: Present and past. In: "The Physical Geography of the Mediterranean". J.C. Woodward, (Ed.), pp. 33-67. Oxford: Oxford University Press.
Ronen, E. (2007) Micro-Elements in Agriculture. Practical Hydroponics \& Greenhouses, July/ August, 39.

Salehi, P., Sonboli, A., Eftekhar, F., Nejad-Ebrahimi, S. and Yousefzadi, M. (2005) Essential oil composition, antibacterial and antioxidant activity of oils and various extracts of Ziziphora clinopodioides subsp rigida (Boiss). Biological \& Pharmaceutical Bulletin, 28(10), 1892-1896.

Satooka, H. and Kubo, I. (2012) Effects of thymol on B16-F10 melanoma cells. Journal of Agricultural and Food Chemistry, 60, 2746-2752.

Shaltout, K.H. (2002) Monitoring the flora of the Omayed Biosphere Reserve and Measures for Rehabilitation. Internationl workshop on combating desertification. ALEPPO, Syria Proceedings. UNESCO-MAB Drylands series No.2.

Shaltout, K. and Ahmed, D. (2012) Ecosystem services of the flora of southern mediterranean desert of Egypt. Ethnobotany Research and Applications, 10, 403-422.

Tackholm, V. (1974) "Students' Flora of Egypt", $2^{\text {nd }}$ ed. Cairo.

Tekdal, D., Cingay, B. and Cetner, S. (2018) Determination of soil nutrient status in Vuralia turcica populations growing at different locations in the Central Anatolia Region of Turkey. Turkish J. of Botany, 42, 317-326.

(Received 29/10/2018) accepted 27/1/2019) 


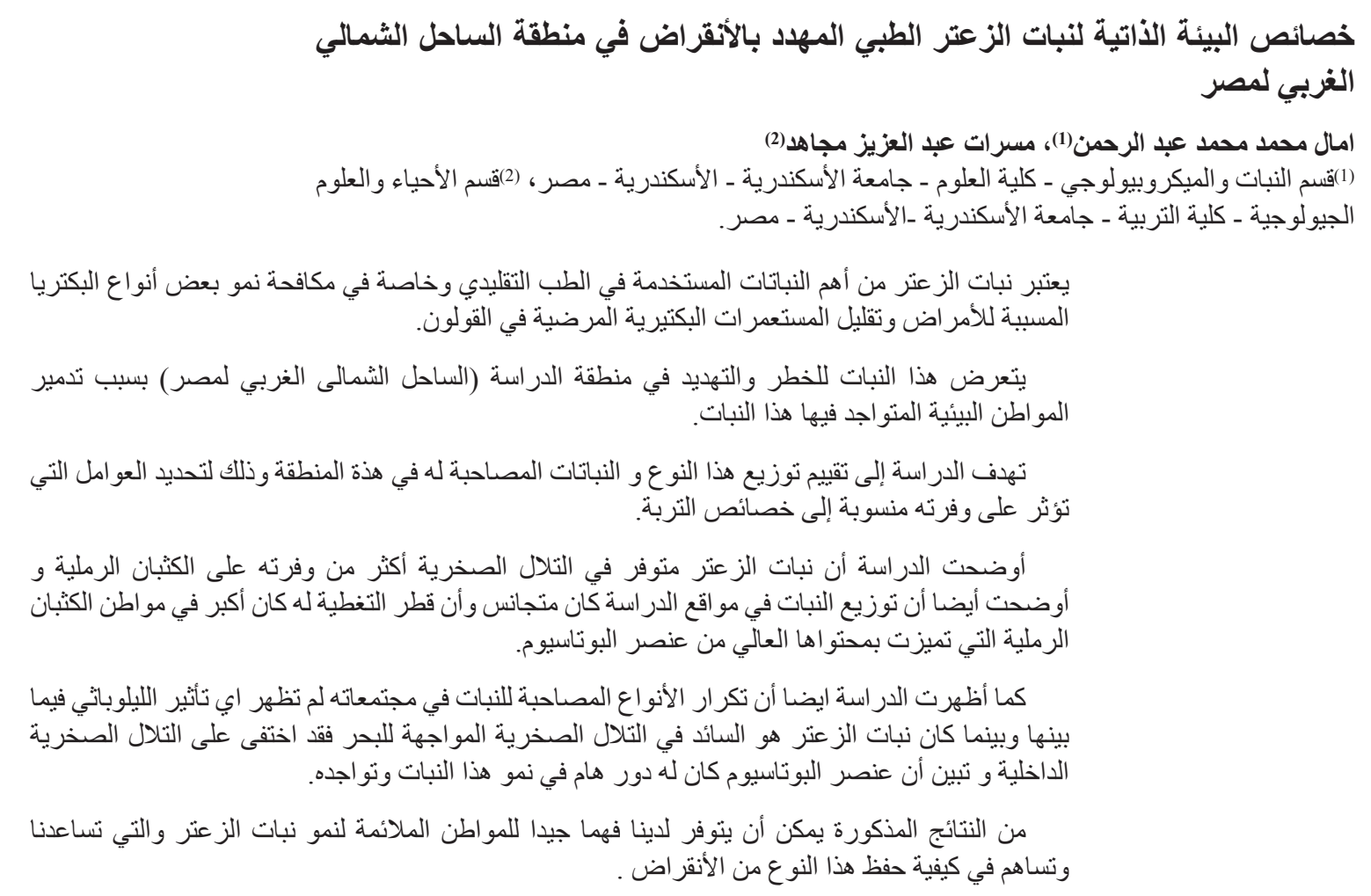

